\title{
The Impact of Oil Exploration and Exploitation on Water Quality and Vegetal Resources in a Rain Forest Ecosystem of Nigeria
}

\author{
Mogborukor J.0.A., Ph.D \\ Department of Geography and Regional Planning, Delta State University, Abraka , P.M.B. 1, Abraka, Nigeria \\ Email: jmogborukor@gmail.com
}

\section{Doi:10.5901/mjss.2014.v5n27p1678}

\section{Abstract}

The oil industry in Nigeria is known to be as a source of revenue and foreign exchange earning to the economy. However, while the industry is perceived as an engine of growth, it is regarded as a mixed blessing to the country. This is as a result of distortions in the environment due to oil spillages and contamination of agricultural lands. Based on these problems, the paper examine the qualities of surface and well waters, bottom sediments, river banks soils and some species of plants in areas of oil exploitation and exploration. Samples of well and surface water, bottom sediments and riverbank soils were collected during the month of June and September 2013. These samples were sent to the laboratory for physio-chemical analysis. The result shows that the values of some samples in some locations were slightly higher than the WHO permissible level for portable water, the same was found in chemical parameters, indicating some level of pollution due to oil spillage. Riverbanks soil values were slightly higher than those of the bottom sediments. Of the twenty-four species of plants evaluated, twenty were impacted slightly due to absorption of toxic nutrients from spilled oil and four non-impacted by oil pollution. To ensure the restoration of the ecosystem, such preventive measures of regulating the activities of oil companies, checking pipe line vandalization, accidental discharge, pre and post-impact assessment by such oil companies should be carried out annually. Lastly, government should enforce pollution control measures and environmental friendly standards.

Keywords: Oil Pollution, Niger Delta, Vegetal Resources, Ecosystem, Swamp forest

\section{Introduction}

In the oil drilling areas of the Niger Delta, the environment is adversely affected as a result of oil exploration and drilling (Ayodele, 1983). It is agreed that oil is the main stay of Nigeria economy, but however, little has been done to protect the environment where this vital activity is carried out from further deterioration. Pollution from oil wells, pipelines, ships and refineries are endemic in the Niger Delta area. The consequence includes contamination of surface and ground water resources. Discharges also affect plants, marine organisms such as plankton, benthos and stresses terrestrial as well as wetland ecosystem.

Furthermore, the effect of gas flares on vegetation, health and micro climate are equally disturbing. The free disposal of gas through flaring demonstrates the marginality of the interest of the oil producing communities. Apart from the deafening howl of the raging fire at gas at gas flare sites, the thick smoke which bellows into the sky fall back as acid rains which has poisoned most rivers and lakes in the Niger Delta area (Alakpodia, 1989). Perhaps, more serious is the colossal waste on the environment by rendering cultivable land unsuitable, and also, the charring of the mangrove and rainforest vegetation with its associated loss of economic and medicinal plants.

Oil pollution in recent times in the petroleum producing area of the Niger Delta of Nigeria like in the case of Sapele, the study area, thousands of hectares of land have been rendered unproductive (see table 1)

\begin{tabular}{|c|c|c|c|c|}
\hline \multirow{2}{*}{ Years } & No of Spills & & Net Volume of Spills in (mb) & \multirow{2}{*}{ Hectares of land affected $\left(\mathrm{km}^{2}\right)$} \\
\hline & Crude oil & Products & Crude oil Products & \\
\hline 1998 & 1 & 4 & - $\quad 7,99.810$ & 7 \\
\hline 1992 & 1 & 14 & $5,240.0019,679.29$ & 10 \\
\hline 1994 & 2 & 7 & $17,898.7849 .19$ & 12 \\
\hline 1995 & - & 5 & $-\quad 5,027.46$ & 9 \\
\hline 1999 & 3 & 12 & $20,922.001,679.28$ & 16 \\
\hline Total & 7 & 42 & $44,060,7827,235.03$ & 54 \\
\hline
\end{tabular}

Source: NNPC Bulletin (2004) 
Some studies carried out on water pollution from oil spillage in Warri River at Opete Eborge (2001). (Abe and Ayodele, 1993), also look at effect of oil exploration and drilling on the general environment of the Niger Delta, while (Akporido, 2002), made a comparison on the quality characteristics of the surface and underground water in Sapele and Oghara oil producing areas of the Niger Delta, but their study did not extend to the soils, bottom sediment and plant species of the area.

\subsection{Purpose of this Research}

This research is carried out with the purpose of looking at soils the surface, well water, bottom sediment and plant species of the area with respect to oil pollution status.

To achieve this aim, the following specific objectives are being pursued:

I. To assess the pollution status of surface and underground water (hand dug wells) around oil drilling locations.

II. To determine the level of oil pollution on soil and bottom sediments along river banks.

III. To evaluate the number of plant species affected by such spills.

\subsection{Study Area}

This study is based on Sapele (Urban and Rural areas). It is located at the co-ordinates of latitudes 50201 and $50501 \mathrm{~N}$ and Longitude 50151and 50411E. It has a total landmass of about $291.37 \mathrm{~km} 2$ (see Fig 1.)

It has a population figure of 142,652 (1991 census). The growth rate of the population was projected at $3.1 \%$ annually. This gave rise to $(179,188)$ in 1999 and $(184,766)$ in the year 2000.

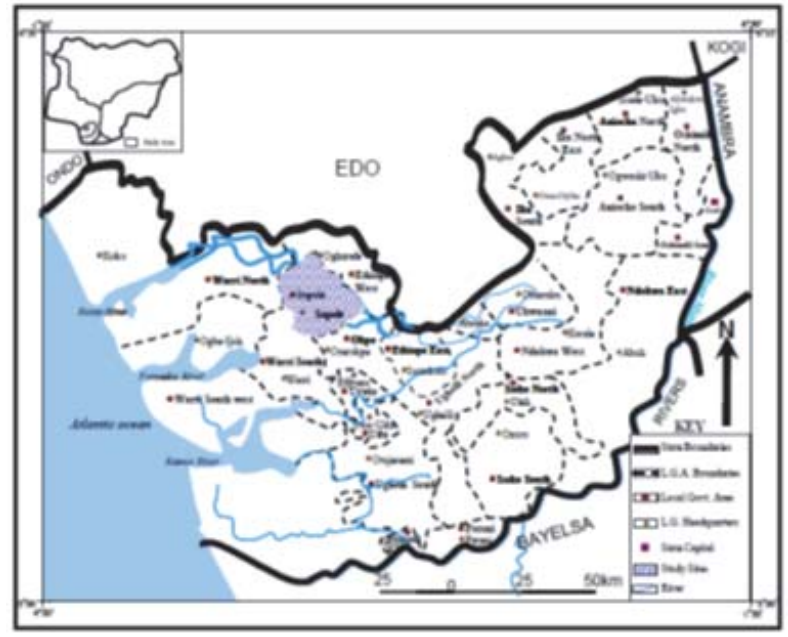

Fig. 1: Map of Delta State Showing Sapele L.G.A with Nigeria Insert

Sapele is located within the Niger Delta region of Nigeria, which has the Agbada, Akata and Benin formation in terms of geology. The rock is made up of the sedimentary type, which falls within the recent Holocene era. (Buckle, 1978) Stated that, a large part of the sedimentary rock formation is very recent in age, having been laid down in the next 12,000 years.

It has a flat terrain with a western part of the area being swampy and towards the Northeast is the undulating plain. Although the area is not hilly, the land slopes towards the Benin and Ethiope rivers in the Eastern part.

Generally, the soils of the area are acidic and non-saline in the freshwater swamps but in the mangrove swamps they are saline and usually near neutrality or slightly acidic (Udo, 1984).

The area is drained by three major rivers namely, Ethiope, Jameison and Benin. These rivers empty their water into the Atlantic Ocean.

The climate is warm and wet throughout the year. It is characterized by sub-equatorial type of climate marked by two dominant seasons, which are wet and dry. The wet season begins from March to October while the dry season spans from November to February. The area experiences almost uniform temperature but with a variation of $1^{\circ} \mathrm{C}$ throughout the year and with a mean of $27^{\circ} \mathrm{C}$. The average monthly rainfall is about $2,277 \mathrm{~mm}$.

The vegetation consists of the rain and freshwater swamp forest. Species of trees which include Iroko 
(Chlorapheraexlessa), Mahogany (Khayaivorensis), Walnut (Lovatrichilloides), Sapele Hardwood. The freshwater swamp forest is made up of mangrove trees (Rhizoperaracemosa), epiphytic plants and Raphia palms (Eleasis guineesis).

However, as a result of anthropogenic activities, cultivated rubber trees and other secondary re-growth forest have replaced the natural vegetation, while few of the natural vegetation are found only along the banks of river Ethiope, Jameison, Benin and in the heart of the swamps. Other secondary re-growth vegetation is found in the hinterlands. Elsewhere, most of the original forest has been cleared for settlement, for firewood and farming.

\section{Material and Methods}

Sampling and sample preservation of surface and groundwater. Samples were collected by method of discrete sampling from five different water sources (WSI-WSV) around crude oil drilling locations. Samples were collected at different depths, the surface and at 10 meters or bottom of wells. The water sources are as follows:

> WSI-Hand dug well for drinking and for domestic use at the Shell Petroleum Development Company (SPDC), site near Sapele (West of the town).

$>$ WSII-Stream near SPDC site near Sapele (South of the town).

$>$ WSIII-Pond of water for domestic use and for fishing at Sapele (East of the town).

$>$ WSIV-Man-made water well for drinking and other domestic uses near the oil flow station at Amukpe (SouthEast).

$>$ WSV-stream water for domestic uses and fishing near Uton River and

Oil drilling location East of Sapele rural area (North-West).

Samples taken from surface and hand dug wells on June-September 2013 were analysed for physiochemical variables in the laboratory using different standard analytical equipment recommended by (WHO, 1978), (ASTM, 1982), (America Public Health Association (APHA, 1976), (Department of Petroleum Resources (DPR, 1997) and (Federal Ministry of Environment standard for testing water and soil samples, 1991)

The physical parameters determined were colours, temperatures, dissolved solids and turbidity while the chemical factors were $\mathrm{pH}$, total hardness, alkalinity, conductivity, sulphate, and nitrate-nitrogen. Also determined were heavy metals like Cadium (Cd), Cupper (Cu), Iron(Fe), and total hydrocarbon content.

Water samples used for analysis were collected using 2 litre sterilized plastic bottle from June-September 2013. These were preserved in accordance with recommended preservation methods and holding period as prescribed by (Schorfield, 1980). The mean of the two samples were calculated and used for the study.

Bottom sediments and riverbank soils were collected from five locations from June-September 2013. The samples were labelled BS1-BS5 and taken to the laboratory for analysis (see fig 2 for collection sites).

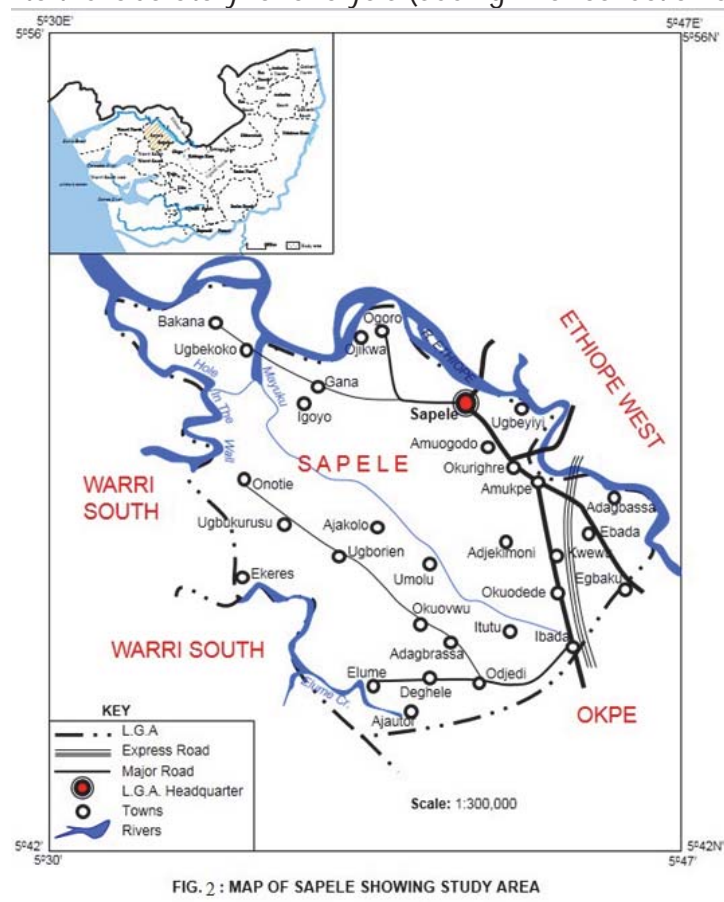


At the laboratory, sediments aliquots were dried at $600 \mathrm{c}$ and homogenized by grinding $5.00 \mathrm{~g}$ of the sediments sample were weighed and digested in acid mixture of equal ratios $(5 \mathrm{~m} / \mathrm{HNO}, \mathrm{HClO} 4$, and $5 \mathrm{ml} \mathrm{HF})$. The beakers containing the samples were kept on hot plates for 30 minutes before they were transferred to the fume cupboard where they remain overnight (UNEP, 1985).

Heavy metals were determined with atomic absorption spectrophotometry, using a Perkin Elmer.

\section{Results and Discussion}

The data collected for the research are presented and discussed in figs 3-8

\subsection{Colour, Total Dissolved Solid and Turbidity}

The colours of the hand dug well close to Shell Petroleum Development Company (SPDC) location WSI with value of 8.5 pt. co and WSII (12.5 PT. co) were above (WHO) maximum acceptable limit of 5 pt. co, while WSIII (3.5 pt. co) and WSV (3.8 pt. co) all conform to maximum permissible level. Turbidity of all samples in all locations was above permissible level of (10NTU) except for WSV (4NTU). TDS of both wells and surface water were generally low, below the acceptable limit of WHO (50mg/l) (see fig. 3).

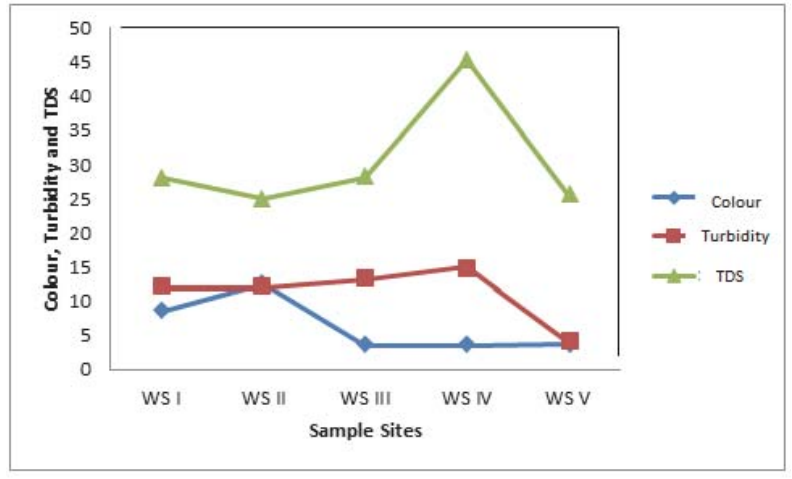

Fig. 3: Variation in Colour, Turbidity and TDS in Surface and Well Water Samples

\subsection{Temperature}

The temperature of water samples from all locations spans from $27.2^{\circ} \mathrm{C}-29^{\circ} \mathrm{C}$. All values fall within WHO desirable unit of $30^{\circ} \mathrm{C}$ and maximum permissible Unit of $34^{\circ} \mathrm{C}$ (See Fig 4).

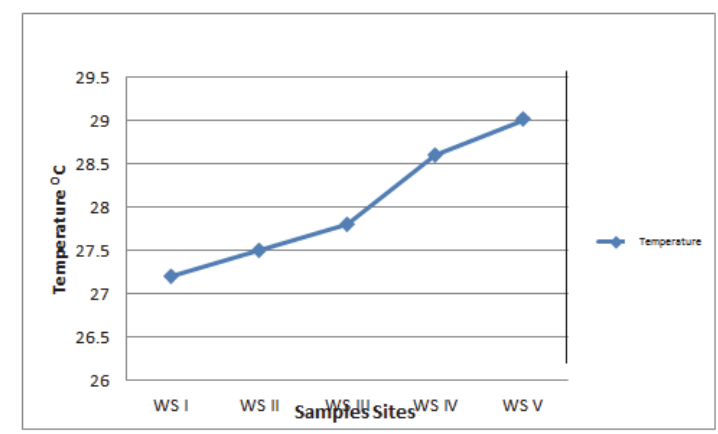

Fig. 4: Temperature Variation from Location to Location

\section{$3.3 \mathrm{pH}$}

The WHO/FEPA maximum permissible limit for $\mathrm{pH}$ is (6.5-9.2). WSI, which is located in the oil drilling area, has a pH value of 5.2, which is below the recommended standard. The implication is that, the water from the hand dug well is 
acidic. WSII has a value of (5.6), WSIII (5.4) indicating also acidity. WSIV (6.9) and WSV (6.8) both indicating non-acidity (alkaline) (see fig. 5). The acidity may be as a result of acid rain, which occurs in the area as a result of the flaring of natural gas, which is a common feature of the drilling areas of Nigeria.

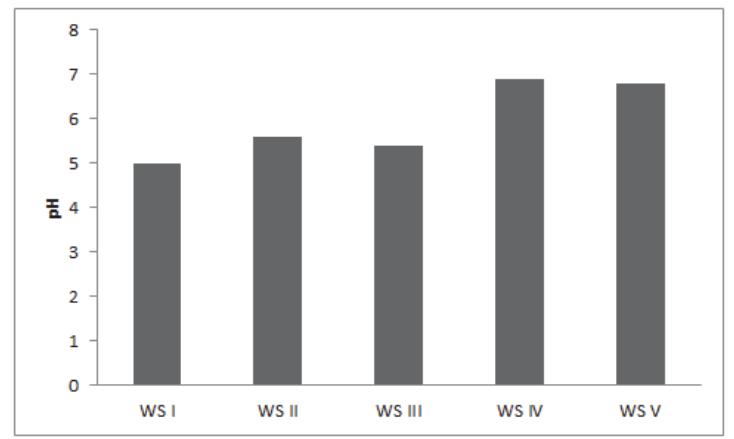

Fig. 5: Variation in $\mathrm{pH}$ from Location to Location

\subsection{Total Hardness, Total Alkalinity and Conductivity}

Total alkalinity had values of $(12.7 \mathrm{mg} / \mathrm{l})$ in WSIII, which was the highest, followed by WSII (10mg/l), WSIV (9.00mg/l), WSV $(5.95 \mathrm{mg} / \mathrm{l})$ and WSI $(5.9 \mathrm{mg} / \mathrm{l})$. All values fall within WHO standard of $(10 \mathrm{mg} / \mathrm{l})$ except for location WSIII. Total hardness $\left(\mathrm{CaCO}_{3}\right)$ level in surface and well water samples were generally low, lower than the $100 \mathrm{mg} / \mathrm{l}$ maximum acceptable threshold of WHO. The values span from $30-45 \mathrm{mg} / \mathrm{l}$. Thus, all waters in the study area are soft.

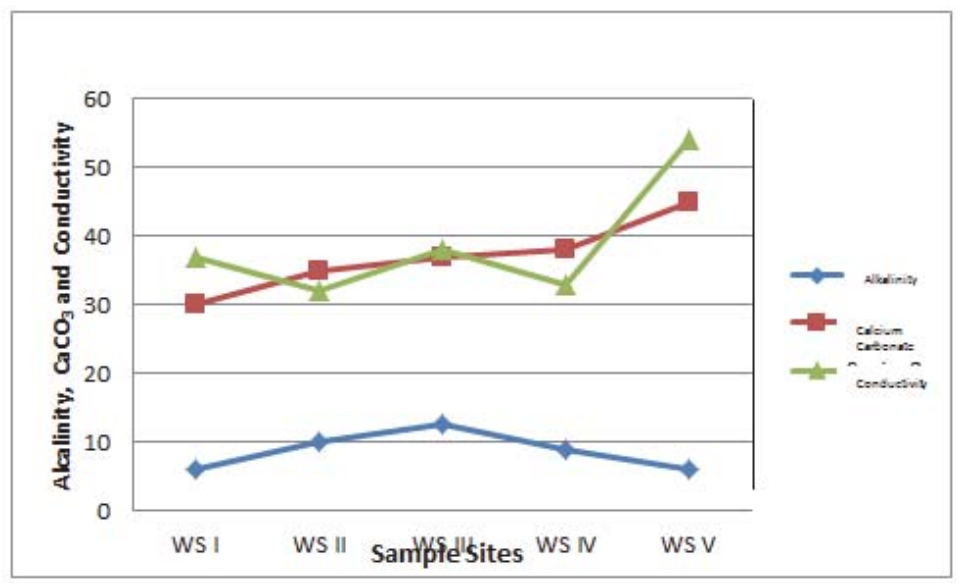

Fig. 6: Variation in Total hardness, Total Alkalinity and Conductivity in the Five Locations

Water samples taken from the five locating indicate that the level of conductivity recorded was below $500 \mathrm{US} / \mathrm{cm}$. the highest value is 54 and the lowest $32 \mathrm{US} / \mathrm{cm}$. (See Fig. 6)

\subsection{Sulphate and Nitrate}

Sulphate levels in all samples were within the WHO limits of $200 \mathrm{mg} / 1 . \mathrm{SO}_{4}{ }^{2+}$ level, which ranged from $(4.0 \mathrm{mg} / \mathrm{l})$ in WSIV to $7.0 \mathrm{mg} / \mathrm{l}$ in WSI.

Nitrate values of samples were generally low, within $10 \mathrm{mg} / \mathrm{l}$ recommended acceptable Unit of WHO. Values in samples ranged from $5 \mathrm{mg} / \mathrm{l}-8 \mathrm{mg} / \mathrm{l}$ in five locations (See Fig. 7) 


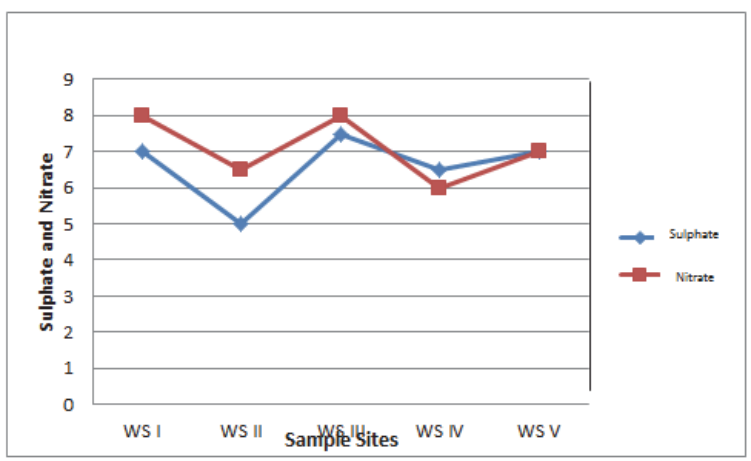

Fig. 7: Variation in Sulphate and Nitrate in all Locations

\subsection{Heavy Metals $(\mathrm{Cu}, \mathrm{Cd}, \mathrm{Fe})$}

Cadmium, permissible value is 0.015 . Sample value ranges from (0.003-0.005) in WSI, (0.002) WSII, (0.005), WSIII, $(0.0003)$ WSIV and (0.004). All are below the recommended value of (9). Copper permissible level is $(1.5 \mathrm{mg} / \mathrm{l})$. All values of copper were below $1.5 \mathrm{mg} / \mathrm{l}$. WSI (0.19), WSII (0.1), WSIII (0.15), WSIV (0.11) and WSV (0.14). Iron permissible level is $(0.1 \mathrm{mg} / \mathrm{l})$. All values were below this value. It span from 0.06-0.2.

\subsection{Total Hydrocarbon Content (THC)}

The maximum permissible level for THC in water is $0.5 \mathrm{mg} / \mathrm{l}(10)$. But study shows that all samples in the five locations were above this value which indicate that all water bodies are slightly contaminated with hydrocarbons (see Fig. 8).

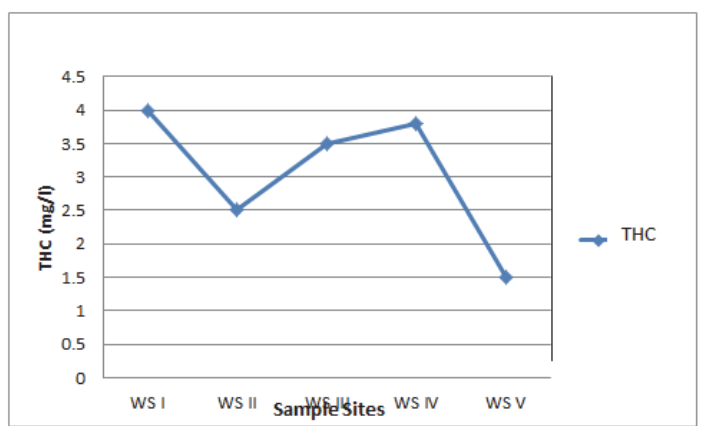

Fig. 8: Variation in Hydrocarbon Contents.

\subsection{Bottom Sediments and River Bank Soils}

Bottom sediments and River bank soils collected from five locations named BSI-BSV (see Fig. 2) were analysed for heavy metals and Total hydrocarbon Content (THC) as shown in table 2.

Table 2: Heavy Metals, THC (ug/g) in Bottom Sediments and Bank Soils

\begin{tabular}{|c|l|c|c|c|c|c|c|}
\hline S/N & Factors & Bottom Sediments & & & & & River Bank Soils \\
\hline & & BS1 & BS2 & BS3 & BS4 & BS5 & \\
\hline 1 & Cadmium(Cd) & 0.120 & 0.132 & 0.143 & 0.125 & 0.145 & 1.226 \\
\hline 2 & Copper $(\mathrm{Cu})$ & 0.03 & 0.01 & 0.25 & 0.06 & 0.03 & 3.354 \\
\hline 3 & Iron $(\mathrm{Fe})$ & 0.56 & 2.30 & 3.35 & 0.67 & 0.42 & 5.770 \\
\hline 4 & Lead $(\mathrm{Pb})$ & 0.310 & 0.220 & 1.380 & 0.230 & 1.310 & 1.750 \\
\hline 5 & Manganese $(\mathrm{Mn})$ & 1.990 & 1.950 & 1.190 & 1.825 & 1.170 & 4.866 \\
\hline 6 & THC & 226.2 & 110.3 & 115.4 & 205.5 & 104.2 & 334.0 \\
\hline
\end{tabular}

Source: Authors Field Study, 2013 
The table reveals that all the metals had concentration slightly higher in soils and bottom sediments than in the open water and wells indicating that cations and anions sink to the bottom and remains bound to sediment particle.

\subsection{The Macrophytes}

The list of macrophytes either on the banks floating or submerged in water are provided below. Approximately, thirty three percent (33\%) of species were evaluated. The full list revealsnumber of impacted plants as provided in table 3 . Twenty (20) taxa were slightly impacted and four (4) non-impacted.

Table 3: Inventory of Plants Species by Crude Oil Spillage

\begin{tabular}{|c|l|c|c|}
\hline S/N & Taxa & Slight Impact & No Impact \\
\hline 1 & Aeschynomenelndica & + & - \\
\hline 2 & AlchorneaCordifolia & - & + \\
\hline 3 & BambusaBambusa & + & - \\
\hline 4 & BrachiariaDeflexa & + & - \\
\hline 5 & CostusAfer & - & + \\
\hline 6 & Chromolaenaodoranta & + & - \\
\hline 7 & Canna Indica & + & - \\
\hline 8 & ElacsisGuineensis & + & - \\
\hline 9 & EichhornedCrassipes & - & - \\
\hline 10 & HarimgenaMadagascaniensis & + & - \\
\hline 11 & HeveaBrasiliensis & + & - \\
\hline 12 & Heterotiserecta & + & - \\
\hline 13 & MusangaCercropioides & + & - \\
\hline 14 & NewbornldraLaevis & + & + \\
\hline 15 & PennisetumPedicellatum & - & - \\
\hline 16 & PennisetumPurpureum & + & - \\
\hline 17 & Persia Gratissima & + & - \\
\hline 18 & RaphiaHookeri & + & - \\
\hline 19 & SacchanimOfficinarum & + & - \\
\hline 20 & SeleniaVenrucosa & + & - \\
\hline 21 & SyndrellaNudiflora & + & \\
\hline 22 & Smilax Krausiana & + & \\
\hline 23 & VitexDoniana & + & \\
\hline & & + & \\
\hline
\end{tabular}

Source: Authors Field Study, 2013

\subsection{Economic Value of Some of the Plants}

Timber is of great economic value to the inhabitants of this ecosystem. It becomes more serious when crude oil spillage affects some species of timber such as Harmgenamadagascariensis and musangemacercropioides.

In a similar study (Egborge, 1999), in the wetlands of Udu-Ughievwen Communities in the Niger Delta area of Nigeria, it was discovered that a number of plants which are of high medicinal value, were affected by crude oil spillage. In this study, such plants with medicinal value impacted include Alchornea Cordiforlia used in controlling stomachaches. Anthocleista Vogeli used for traditional treatment of impotency and Costus afar, which removes skin rashes, and worms from the alimentary system were also affected.

\section{Conclusions}

The drive to tap natural resources to the advantage of man has translated into a number of environmental problems, (Jimoh, 1997)

This study has looked at the consequences of oil exploration and drilling on an ecosystem using Sapele as a case study. This work was able to reveal that, pollution from oil spillage to some extent have rendered water in rivers, streams and wells unfit for human consumption. Also, some medicinal plants species have been rendered impotent in their value. 
Most farmlands that are close to river courses have their soils rendered unproductive due to contamination from oil spill.

In order to avert the aforementioned consequences, preventive measures such as ensuring that the law of the land adequately protects the fundamental rights of the inhabitants of the oil producing areas of the country who depends solely on the land and water resources as means of livelihood. This may require the revision of the existing legislation in the oil industries so that the welfare aspect of oil exploration may be properly addressed. There may be need for government to take appropriate regulatory measures to ensure the restoration of the ecosystem of the producing areas. In this regards, the government should enforce possible pollution control measures and impose environmental friendly standards.

The concentration of efforts on checking oil pollution either through sabotage, accidental discharged or pipeline vandalization should be carried out and create quick response to cases of oil spillages .

All oil companies should put in place measures at prohibiting gas flaring. Such gas should be piped and distributed for domestic and industrial use as it is done in most developed countries.

Finally, it is also imperative for government to introduce a system that would make all the oil companies operating in the country to constitute an ecological insurance policy for the purpose of compensation to the affected people.

\section{Acknowledgements}

The author would like to thank Dr. Iwegbue Maxwell of Chemistry Department, Delta State University, Abraka who help to carry out analysis of most of the water samples and Dr. Abel Abotutu of the Department of Geography and Regional Planning of the same university for his remarks on the paper.

\section{References}

Abe, F. and Ayodele, A. (1993). "Oil exploration/drilling and the environment. A Paper Presented at the National Conference of Development and the Environment". Nigeria Institute for Social and Economic Research (NISER), Ibadan, Nigeria.

Akporido S. O., Emuobonuvie, I. J. and Akporido, C. E. (2002). "A study of the quality characteristics of surface and underground water in Sapele of Delta State". Nigeria. Journal of Science and Environment, 2 pp 17-22. Publication of the Facilities of Science and Agriculture, Delta State University, Abraka, Nigeria.

Alakpodia, I. J. (1989). "The effect of gas flaring on the micro climate and adjacent vegetation in Isoko Area of Bendel State". (Unpublished M.Sc. Thesis, University of Ibandan).

APHA, (1976). Standard methods for the examination of water America Public Health Association, New York.

ASTM, (1982). Book of ASTM standards part32, sampling of water American Society for Testing Materials. Philadelphia.

Ayodele, A. (1983). Energy development and utilization in Nigeria. NISER Publication. Ibadan, Nigeria.

Buckle, C. (1978). Land forms in Africa. Esset Longman.

D.R.P, (1977). Department of Petroleum Resources (DRP).

Egborge, A.B.M. (1999). Survey and documentation of endangered biodiversity of the wetlands of Udu-Ughievwen communities of Nigeria Delta of Nigeria. DEENET Report to the Netherlands Committee for ICON Amsterdam.

Egborge, A. B. M. (2001). Pollution of Warri River at Opete Warri: Ben Miller Publication.

FEPA, (1991). Federal environmental protection agency. Guidelines and Standards for Environmental Pollution Control in Nigeria, FEPA Abuja.

Jimoh, H. I. (1997). "Individual rainfall events and sediments generation on different surfaces in llorin, Nigeria". A Ph.D. Thesis Submitted to the Department of Geography, University of Ilorin, Nigeria.

NNPC (2000). Nigeria National Petroleum Corporation, Monthly Bulletin.

Schorfield, T. (1980). Sampling of water and practical aspects of sample collection. Water pollution control. Pp 468-476.

Udo, E. J., Albedi, M., and Fagbami, E. (1984). Phosphorus status of some saline and non- saline soils of the Niger Delta. Plant and Soil. 7. Pp. 327-335

UNEP, (1985). Reference method for marine pollution studies. NO.31-39.

W.H.O, (1978). Drinking water standard. Geneva 